\title{
Commentary: Does valve choice matter in patients receiving hemodialysis?
}

\author{
From the a Department of Surgery, Max Rady College of Medicine, University of Manitoba, Winnipeg, Manitoba, \\ Canada; and ${ }^{\mathrm{b}}$ Cardiac Sciences Program, St. Boniface Hospital, Winnipeg, Manitoba, Canada. \\ Disclosures: R.C.A. has received an unrestricted educational grant from Pfizer Canada Inc and honoraria from \\ Mallinckrodt Pharmaceuticals for work unrelated to this article. All other authors have nothing to disclose \\ with regard to commercial support. \\ Received for publication Sept 15, 2018; accepted for publication Sept 17, 2018; available ahead of print Nov 7, \\ 2018. \\ Address for reprints: Michael H. Yamashita, MDCM, MPH, St Boniface Hospital, Y3519, 369 Tache Ave, Win- \\ nipeg, Manitoba, R2H 2A6, Canada (E-mail: myamashita@sbgh.mb.ca). \\ J Thorac Cardiovasc Surg 2019;157:2187-8 \\ $0022-5223 / \$ 36.00$ \\ Copyright (C) 2019 by The American Association for Thoracic Surgery \\ https://doi.org/10.1016/j.jtcvs.2018.09.055
}

Weiang Yan, MD, ${ }^{\mathrm{a}, \mathrm{b}}$ Rakesh C. Arora, MD, PhD, ${ }^{\mathrm{a}, \mathrm{b}}$ and Michael H. Yamashita, MDCM, MPH ${ }^{\mathrm{a}, \mathrm{b}}$

Central Message
Our understanding of the intimate relationship between renal function and cardiovascular events has increased significantly during the past 3 decades. Progressive renal dysfunction results in marked disturbances of calciumphosphate balance and other metabolic pathways that predispose patients to accelerated progression of calcific aortic stenosis. ${ }^{1}$ As the prevalence of end-stage renal disease increases, so does the number of patients receiving hemodialysis presenting with aortic stenosis requiring surgical intervention. ${ }^{2}$

The choice of prosthesis in this patient population, whether bioprosthetic or mechanical, has been a hotly debated topic during the past 20 years. By the late 1990s, several case reports of accelerated bioprosthetic valve calcification in patients receiving hemodialysis led the American College of Cardiology and the American Heart Association to recommend mechanical valves instead of bioprosthetic valves for these patients. ${ }^{3}$ In the years since this recommendation, however, several retrospective cohort studies of dialysis patients have shown similar shortto intermediate-term survival after bioprosthetic and mechanical aortic valve replacement (AVR). ${ }^{4,5}$ In addition, some reports have demonstrated lower rates of valve-related complications with bioprosthetic valves. ${ }^{6,7}$ In light of the observed poor long-term survival of patients undergoing hemodialysis, guidelines have moved away from universally recommending mechanical prostheses, with some guidelines even suggesting bioprosthetic valves in this patient population. ${ }^{8}$ High-quality data on long-term outcomes after bioprosthetic or mechanical AVR, however, remain sparse. ${ }^{9}$

Nakatsu and colleagues ${ }^{10}$ attempt to address this problem in their article in this issue of the Journal with a large retrospective cohort analysis of intermediate-term outcomes in 491 patients undergoing hemodialysis requiring surgical AVR. The authors ${ }^{10}$ present a commendable $98 \%$

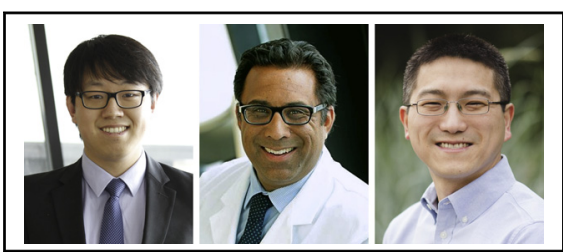

Left to right. Weiang Yan, MD, Rakesh C. Arora, MD, PhD, Michael H. Yamashita, MDCM, MPH

Despite increasing short- to intermediate-term data, longer follow-up is required to determine whether patients receiving hemodialysis will benefit from the improved durability of mechanical valves.

See Article page 2177.

follow-up, with extensive analyses of the most relevant outcomes. A subgroup analysis of the 183 patients who underwent first-time isolated AVR attempts to eliminate the effects of concomitant surgery, whereas a detailed propensity analysis tries to minimize the selection bias.

The results from this study are perhaps anticipated and reinforce current perceptions. All-cause mortality was high at 5 years, regardless of prosthesis type, and valve-related events were not the major cause of mortality for patients with either valve type. Dialysis-related complications continue to be the main driver of poor survival, despite appropriate cardiac surgery. Of note, however, were the findings that structural valve deterioration was seen in only 6 patients, all with bioprosthetic valves, and that patients with mechanical valves trended to have higher rates of valve-related death, driven by bleeding events and sudden death.

A limitation of this study was the short mean follow-up of 2.5 years. A precipitous drop in the numbers at risk beyond 3 years of follow-up readily reflects this shortcoming. In fact, $45 \%$ of patients included in this study, including two-thirds of the bioprosthetic cohort, underwent their surgery within the last 3 years of the study period. This is earlier than one would anticipate finding structural valve deterioration in a bioprosthetic valve and limits the ability to detect it. The question of whether patients receiving hemodialysis will benefit from longer mechanical valve durability remains unanswered. Trials with longer follow-up are critical to answering this important question. 


\section{References}

1. Rattazzi M, Bertacco E, Del Vecchio A, Puato M, Faggin E, Pauletto P. Aortic valve calcification in chronic kidney disease. Nephrol Dial Transplant. 2013; 28:2968-76.

2. United States Renal Data System. 2017 USRDS annual data report: epidemiology of kidney disease in the United States. Bethesda (MD). Available at: https://www.usrds.org/adr.aspx.

3. Bonow RO, Carabello B, de Leon AC Jr, Edmunds LH Jr, Fedderly BJ, Freed MD, et al. Guidelines for the management of patients with valvular heart disease: executive summary: A report of the American College of Cardiology/ American Heart Association Task Force on Practice Guidelines (Committee on Management of Patients with Valvular Heart Disease). Circulation. 1998;98: 1949-84.

4. Herzog CA, Ma JZ, Collins AJ. Long-term survival of dialysis patients in the United States with prosthetic heart valves: Should ACC/AHA practice guidelines on valve selection be modified? Circulation. 2002;105:1336-41.

5. Kaplon RJ, Cosgrove DM III, Gillinov AM, Lytle BW, Blackstone EH, Smedira NG. Cardiac valve replacement in patients on dialysis: influence of prosthesis on survival. Ann Thorac Surg. 2000;70:438-41.

6. Lucke JC, Samy RN, Atkins BZ, Silvestry SC, Douglas JM Jr, Schwab SJ, et al. Results of valve replacement with mechanical and biological prostheses in chronic renal dialysis patients. Ann Thorac Surg. 1997;64:129-32; discussion 132-3.

7. Brinkman WT, Williams WH, Guyton RA, Jones EL, Craver JM. Valve replacement in patients on chronic renal dialysis: implications for valve prosthesis selection. Ann Thorac Surg. 2002;74:37-42; discussion 42.

8. Jamieson WR, Cartier PC, Allard M, Boutin C, Burwash IG, Butany J, et al. Surgical management of valvular heart disease 2004. Can J Cardiol. 2004;20(Suppl E):7E-120E.

9. Chan V, Jamieson WR, Fleisher AG, Denmark D, Chan F, Germann E. Valve replacement surgery in end-stage renal failure: mechanical prostheses versus bioprostheses. Ann Thorac Surg. 2006;81:857-62.

10. Nakatsu T, Minakata K, Tanaka S, Minatoya K, PROGRESS-Kyoto Investigators. Intermediate-term outcomes of aortic valve replacement with bioprosthetic or mechanical valves in patients on hemodialysis. J Thorac Cardiovasc Surg. 2019;157:2177-86.e3. 